\title{
Consumption of fibrinolytic proteins in menstrual fluid from women with normal menstrual blood loss
}

\author{
SA CEDERHOLM-WILLIAMS, MARGARET CP REES, AC TURNBULL \\ From the Nuffield Department of Obstetrics and Gynaecology, John Radcliffe. Hospital, Oxford OX3 9DU
}

SUMMARY Fibrinolytic proteins in menstrual fluid collected from women with normal menstrual blood loss $(<80 \mathrm{ml})$ were found to be completely exhausted. High levels of tissue plasminogen activator, fibrin(ogen) degradation products, and plasmin-inhibitor complexes were present, but little fibrinolytically active plasmin remained. No difference was observed between days 1 and 2 of menstruation.

The fluidity of menstrual discharge has intrigued investigators for many years, ${ }^{2}$ and the absence of clottable fibrinogen has been attributed to high fibrinolytic activity. The presence of plasminogen activator in endometrial tissue ${ }^{3}$ and the possibility that an increased level of this enzyme is an aetiological factor in menorrhagia have led to the use of synthetic antifibrinolytic agents to reduce excessive menstrual blood loss. ${ }^{4}$

Since these reports the molecular control of the fibrinolytic enzyme system has been explored in detail. ${ }^{5}$ Plasmin, the major fibrinolytic protease, is generated from the inactive proenzyme plasminogen by the action of the enzyme plasminogen activator, present only in trace amounts in peripheral blood. ${ }^{78}$ The action of plasmin on fibrin(ogen) is regulated by the inhibitors fast acting $\alpha_{2}$-antiplasmin and slow acting $\alpha_{2}$-macroglobulin. ${ }^{9}{ }^{10}$ Fibrin, the primary substrate of plasmin, also plays an important regulatory role: both plasminogen activator and plasminogen bind to fibrin, bringing the proteins into catalytic contact and causing the generation of plasmin activity. In addition, fibrin bound plasmin is protected from $\alpha_{2}$-antiplasmin inhibition, localising the proteolytic action of plasmin to the immediate vicinity of the fibrin clot. ${ }^{56}$

The recent exploration of the fibrinolytic enzyme system has been facilitated by methodological advances, notably the preparation of antibodies to fibrinolytic proteins and the development of tripeptide chromogenic substrates for functional assays. We have used these techniques to re-examine fibrinolytic proteins in menstrual fluid collected from women with normal menstrual blood loss (less

Accepted for publication 15 May 1984 than $80 \mathrm{ml}$ " " to see if further information can be obtained concerning the process of menstrual bleeding.

\section{Subjects and methods}

\section{SUBJECTS}

Menstrual fluid was collected from 12 women using Tassaway vaginal cups (containing no anticoagulant) inserted for $2 \mathrm{~h}$ during the first and second days of menstruation. Day one was taken to extend for $24 \mathrm{~h}$ from the onset of menstrual flow. The women (aged 25 to 46 years) all had regular menstrual cycles with an average cycle length of 28 days (range 23 to 33 days). Pelvic examination revealed no abnormality. None of the women had used either oral or intrauterine contraception or received hormone treatment for at least four months before the study. Coitus was prohibited for $24 \mathrm{~h}$ before sampling. The women collected all their soiled sanitary devices during two successive menstruations and menstrual blood loss was estimated using the alkaline haematin dilution method. ${ }^{12}$

\section{METHODS}

The menstrual fluid collected was centrifuged at $1800 \mathrm{~g}$ for $30 \mathrm{~min}$ at $10^{\circ} \mathrm{C}$; the supernatant was removed and stored at $-20^{\circ} \mathrm{C}$ until analysis.

When all the samples of menstrual fluid supernatant had been collected the assays were performed in single batches. Plasminogen, $\alpha_{2}$-antiplasmin, $\alpha_{2-}$ macroglobulin, fibrin(ogen) related antigens, IgG, and serum albumin were each assayed by the radial immunodiffusion technique ${ }^{13}$; the results were related to calibration curves constructed from pooled peripheral plasma of known plasma factor 
concentrations (Hoechst standard plasma). A correction was made for the presence of $1 / 10$ th volume anticoagulant in peripheral plasma samples.

Fast acting antiplasmin ( $\alpha_{2}$-antiplasmin) activity was assayed $^{14}$ using the Coatest antiplasmin kit (KabiVitrum, Stockholm) adapted to the Gilford 3800 reaction rate analyser (Gilford Inc, Ohio, USA). Enzymatically active plasmin was assayed by adding $5 \mu \mathrm{l}$ of menstrual fluid supernatant to $700 \mu \mathrm{l}$ $(1 \mathrm{mmol} / \mathrm{l})$ of the plasmin specific chromogenic substrate D-valyl-leucyl-lysine-p-nitroanalide (KabiVitrum, Stockholm) and measuring the reaction at $405 \mathrm{~nm}$ at $37^{\circ} \mathrm{C}$ over a $30 \mathrm{~s}$ interval. Concentrations were determined by reference to a standard curve constructed from dilutions of plasmin.

Plasminogen activator activity was measured in euglobulin fractions. ${ }^{15}$ Duplicate volumes $(25 \mu \mathrm{l})$ of each euglobulin fraction were incubated on fibrin plates $^{16}$ and the lysis areas related to concentrations by reference to a standard curve constructed from serial dilutions of urokinase (CTA units). Similar assays were also carried out using fibrin-agar plates $^{17}$ containing rabbit $\mathrm{IgG}$ fraction raised against human uterine tissue plasminogen activator. Proteolytic activity remaining after inhibition of the plasminogen activator represents the fibrinolytic activity of free plasmin. All antibodies used in this study were prepared by our research group.

\section{Results}

All the women had a normal menstrual blood loss of less than $80 \mathrm{ml}$ (median $35 \mathrm{ml}$, range $15-75 \mathrm{ml}$ )." There were no significant differences (Student's t test) for any factor when samples collected on days 1 and 2 were compared; therefore the following results are presented as the mean values for two samples (days one and two) from the 12 women. In no instance was the presence of clots observed in the vaginal cups.

Table 1 compares the concentrations of albumin, IgG, and fibrinolytic proteins in menstrual fluid supernatant with those found in pooled peripheral plasma. Adjustment was made to account for the presence of $1 / 10$ th volume trisodium citrate in the plasma pool, and an average packed cell volume of 0.42 for menstrual blood was assumed. Concentrations of albumin, IgG, $\alpha_{2}$-antiplasmin, $\alpha_{2-}$ macroglobulin, plasmin(ogen), and fibrin(ogen) antigens in menstrual fluid supernatant were similar to or slightly higher than those in peripheral plasma. Plasminogen activator activity was much higher than in peripheral plasma, and fast acting $\alpha_{2}$-antiplasmin activity was zero in each sample (Table 2). Although high levels of enzymatically active plasmin were found using the chromogenic peptide assay, there was low fibrinolytic activity $(17 \%)$ when assayed with inhibiting antibody against plasminogen activator, which suggests that little free plasmin is present in menstrual fluid (Table 2).

\section{Discussion}

This study has shown that menstrual fluid supernatant has features that are distinct from those of serum obtained from the clotting of peripheral venous blood. The very high concentrations $(3.7 \mathrm{mg} / \mathrm{ml})$ of fibrin(ogen) related antigen (normally $<5 \mu \mathrm{g} / \mathrm{ml}$ in serum), enzymatically active plasmin (normally undetectable), and high levels of plasminogen

Table 2 Activity levels for fibrinolytic proteins present in menstrual fuid supernatant and peripheral plasma

\begin{tabular}{|c|c|c|}
\hline & $\begin{array}{l}\text { Menstrual fuid } \\
\text { supernatant } \\
(n=24) \\
(\text { mean } \pm S D)\end{array}$ & $\begin{array}{l}\text { Pooled peripheral } \\
\text { plasma } \\
\text { (mean) }\end{array}$ \\
\hline Plasmin activity $(\mu \mathrm{mol} / \mathrm{l})$ & $0.83 \pm 0.97$ & 0 \\
\hline $\begin{array}{l}\text { Plasminogen activator } \\
\text { (CTA units/ml) } \\
\text { Plasminogen activator }+\end{array}$ & \multicolumn{2}{|c|}{1.04 (range $0-3.5) 0.15$ (range $0-0.2$ ) } \\
\hline $\begin{array}{l}\text { anti-PA antibody. } \\
\text { (\% inhibition) }\end{array}$ & $83 \pm 28$ & ND \\
\hline$\alpha_{2}$-antiplasmin (\%) & 0 & $100 \pm .20 \%$ \\
\hline
\end{tabular}

ND $=$ not done.

Table 1 Protein concentrations in menstrual fuid supernatant and peripheral plasma

\begin{tabular}{|c|c|c|c|c|}
\hline & \multicolumn{2}{|c|}{ Menstrual fuid supernatant $(n=24)$} & \multicolumn{2}{|c|}{ Pooled peripheral plasma } \\
\hline & $\begin{array}{l}\text { Mean } \pm S D \\
(g / l)\end{array}$ & $\begin{array}{l}\text { Mean } \\
(\mu \mathrm{mol} / \mathrm{l})\end{array}$ & $\begin{array}{l}\text { Mean } \\
(g / l)\end{array}$ & $\begin{array}{l}\text { Mean } \\
(\mu m o l / l)\end{array}$ \\
\hline IgG & $\begin{array}{r}12.5 \pm 2.3 \\
43.6 \pm 11.8\end{array}$ & $\begin{array}{l}84 \cdot 5 \\
641\end{array}$ & $\begin{array}{l}12 \cdot 0 \pm 2 \cdot 3 \\
44 \pm 8 \cdot 8\end{array}$ & $\begin{array}{l}81 \cdot 1 \\
647\end{array}$ \\
\hline $\begin{array}{l}\text { Fibrin(ogen) } \\
\quad \text { antigen } \\
\text { Plasmin(ogen) } \\
\alpha_{2} \text {-antiplasmin } \\
\alpha_{2} \text {-macroglobulin }\end{array}$ & $\begin{array}{l}3.71 \pm 2.3 \\
0.17 \pm 0.05 \\
0.56 \pm 0.12 \\
2.51 \pm 0.37\end{array}$ & $\begin{array}{l}10.9 \\
1.88 \\
0.81 \\
3.49\end{array}$ & $\begin{array}{l}2.25 \pm 0.54 \\
0.15 \pm 0.03 \\
0.70 \pm 0.14 \\
2.65 \pm 0.61\end{array}$ & $\begin{array}{l}6.62 \\
1.67 \\
1.0 \\
3.68\end{array}$ \\
\hline
\end{tabular}

The plasma pool was prepared from blood drawn from 20 normal subjects. Concentrations were determined using a standard plasma from Hoechst Pharmaceuticals, Hounslow. 
activator, together with undetectable levels of functionally active $\alpha_{2}$-antiplasmin are in striking contrast to normal serum. ${ }^{18}$ That albumin and IgG, the major plasma proteins, were present in menstrual fluid in concentrations similar to those found in peripheral venous blood indicates the absence of haemoconcentration or haemodilution phenomena that would have otherwise invalidated these comparisons.

Menstrual fluid was obtained from the vagina instead of the uterine cavity since this procedure is noninvasive and was the method of collection most acceptable by the women. In addition, the presence of a probe in the uterine cavity is thought to affect endometrial blood flow, at least in sheep. ${ }^{19}$

Our findings show an exhaustive activation of the fibrinolytic mechanism in normal menstrual discharge which is probably responsible for its fluid properties. This study did not indicate whether fibrinogen or fibrin is digested before or after clotting, though plasminogen activation is normally a fibrin dependent reaction..$^{58}$ The detection of substantial quantities $(0.83 \mu \mathrm{mol} / \mathrm{l})$ of enzymatically active plasmin that retained little fibrinolytic activity on fibrin plates is probably explained by the action of $\alpha_{2}$-macroglobulin. This inhibitor inactivates a wide range of proteases by an "entrapment" mechanism, which destroys fibrinolytic activity while leaving enzymatic activity still detectable using small synthetic substrates. ${ }^{11}$ The enzyme activity so detected may therefore represent the complex between plasmin and the slow reacting $\alpha_{2-}$ macroglobulin.

As inactivation of all the fast acting $\alpha_{2-}$ antiplasmin $(0.81 \mu \mathrm{mol} / \mathrm{l})$ in menstrual fluid represents $0.81 \mu \mathrm{mol} / \mathrm{l}$ plasmin(ogen) consumed (the reaction has a 1:1 stoichiometry) then the remaining plasmin $(1.88-0.81=1.07 \mu \mathrm{mol} / \mathrm{l})$ would react with $\alpha_{2}$-macroglobulin, giving rise to the $0.83 \mu \mathrm{mol} / \mathrm{l}$ activity detected by chromogenic assay. $\alpha_{2-}$ macroglobulin represents a substantial reservoir of inhibitory activity since each mole can inhibit two moles of protease and it is present in a molar excess over plasmin. The discrepancy $(0.24 \mu \mathrm{mol} / \mathrm{l})$ between expected and measured figures may be due to the small contribution of $\alpha_{1}$-antitrypsin inactivating plasmin. The potent proteolytic activity of plasmin is thus confined to the uterine compartment and does not appear to extend to the vaginal tract.

These observations are especially important since they have been made on menstrual fluid collected from subjects with normal blood loss $(<80 \mathrm{ml})^{\prime \prime}$ assessed by objective procedures. That normal menstrual blood appears to be fibrinolytically exhausted strongly suggests that other factors within the endometrium are responsible for the heavy mens- trual blood loss that is ameanable to treatment with synthetic antifibrinolytic agents. ${ }^{40}$

The excellent technical assistance of Mrs F Daniels is acknowledged. This study was supported by grants from the British Heart Foundation (grant no 83/10), the Medical Research Council, and Parke-Davis Pharmaceuticals.

\section{References}

' Whitehouse HB. The physiology and pathology of uterine haemorrhage. Lancet 1914;i:854-77, 951-7.

${ }^{2}$ Smith OW, Smith GVS. A fibrinolytic enzyme in menstruation and late pregnancy toxaemia. Science $1945 ; 102$ : $253-4$.

${ }^{3}$ Albrechtsen OK. The fibrinolytic activity of the human endometrium. Acta Endocrinol 1956;23:207-18.

${ }^{4}$ Nilsson IM, Bjorkman SE. Experiences with :-aminocaproic acid ( $\because$-ACA) in the treatment of profuse menstruation. Acta Med Scand 1965; 177:445-57.

s Collen D. On the regulation and control of fibrinolysis. Thromb Haemostas 1980;43:77-89.

- Cederholm-Williams SA. Control of fibrinolysis. Br J Hosp Med 1983;30: 107-10

' Bergsdorf N, Nilsson T, Wallen P. An enzyme-linked immunosorbent assay for determination of tissue plasminogen activator applied to patients with thrombo embolic diseases. Thromb Haemostas 1983;50:740-4.

${ }^{*}$ Cederholm-Williams SA, Sharp AA. The vessel wall and the control of fibrinolysis. In: Woolf N, ed. Biology and pathology of the vessel wall. New York: Praeger Publishers, 1983:147-59.

- Wiman B, Collen D. On the kinetics of the reactions between antiplasmin and plasmin. Eur J Biochem 1978;84:573-8.

${ }^{10}$ Starkey PM. $\alpha$-2-macroglobulin: a review. In: Collen D, Wiman B, Verstraete M, eds. The physiological inhibitors of coagulation and fibrinolysis. Amsterdam: Elsevier/North Holland, 1979:1-11.

" Hallberg L, Hogdahl AM, Nilsson M, Rybo G. Menstrual blood loss-a population study. Acta Obstet Gvnaecol Scand 1966; 45:320-51.

12 Hallberg L, Nilsson L. Determination of menstrual blood loss. Scand J Clin Lab Invest 1964;16:244-8.

${ }^{13}$ Mancini G, Carbonara AO, Heremans JF. Immunochemical quantitation of antigens by single radial immunodiffusion. Immunochemistry 1965;2:235-40.

${ }^{14}$ Teger-Nilsson AC, Friberger P, Gyzander E. Determination of a new rapid plasmin inhibitor in human blood by means of a plasmin specific tripeptide substrate. Scand J Clin Lab Invest 1977;37:403-9.

is Milstone $\mathbf{H}$. A factor in normal blood which participates in streptococcal fibrinolysis. J Immunol 1941;42:109-16.

${ }^{16}$ Astrup T, Mullertz S. The fibrin plate method for estimating fibrinolytic activity. Arch Biochem Biophys 1952;40:346-51.

${ }^{17}$ Holmstrom B. Streptokinase assay on large agar diffusion plates. Acta Chemica Scand 1965; 19:1549-54.

${ }^{1 *}$ Cederholm-Williams SA. Concentration of plasminogen and antiplasmin in plasma and serum. J Clin Pathol 1981;34:97981.

14 Fraser IS, Brown BW, Matthew PT. Endometrial blood flow in anaethetised sheep as measured with krypton-85 clearance and microsphere techniques. J Exp Physiol 1980;65:19-26.

${ }^{20}$ Hahn L, Rybo G. Fibrinogen-fibrin degradation products in menstrual blood from women with normal and excessive menstrual blood loss. Acta Obstet Gynaecol Scand 1975;54:119-27.

Requests for reprints to: Dr SA Cederholm-Williams, Nuffield Department of Obstetrics and Gynaecology, John Radcliffe Hospital, Oxford OX3 9DU, England. 